\title{
ETNOTEKNOLOGI BERBURU DAYAK KUBIN DI DESA MANGGALA KECAMATAN PINOH SELATAN KABUPATEN MELAWI
}

\author{
(Hunting Etnotecnology of Dayak Kubin in Manggala Vilage Pinoh Selatan District \\ Melawi Regency)
}

\author{
Ari Firdaus, Siti Masitoh Kartikawati, Emi Roslinda \\ Fakultas Kehutanan Universitastanjungpura, Jalan Daya Nasional Pontianak 78124 \\ Email : arifirdaus091@gmal.com
}

\begin{abstract}
Traditional hunting is hunting using traditional tools, such as traps, chopsticks, spears, arrows, root and barracks to hunt fish in the river. Hunting equipment used is simple, the material is easily obtained in the surrounding environment and can be assembled and made by yourself. and crossbow. Manggala Village is a village in Melawi Regency where the people are still doing hunting activities, especially the Dayak Kubin tribe, even though Manggala Village has become the center of South Pinoh Sub-district and the conditions are already relatively advanced. This study aims to record the species of animals that are targeted by the Dayak Kubin community in Manggala village, Pinoh Subdistrict, South Melawi District, and examine the hunting techniques and tools used for hunting Dayak Kubin. This study uses a survey method, the determination of respondent with purposive sampling. Number of animal species utilized and targeted by Dayak Kubin people in Manggala Village, Pinoh Selatan District, Melawi Regency, as many as 12 species of 12 families, 2 types of animals, 1 family consisting of 1 species. Dayak Kubin hunting activities carried out by groups and individuals. Tools used in hunting activities are spears, snares, trawl, traps and fishing rods. Hunting techniques carried out by the Dayak Kubin people still use traditional methods such as the materials used are still derived from forest plants such as leaves and bark made concoctions, perform rituals before hunting.
\end{abstract}

Keywords:Dayak Cubic Tribe, Etnotecnology, Hunting Technique

\section{PENDAHULUAN}

Kalimantan Barat merupakan salah satu wilayah di Indonesia yang memiliki tingkat keragaman hayati yang tinggi, berbagai macam flora dan fauna endemik yang khas dapat kita temui di hutan Kalimantan Barat. Kekayaan alam ini banyak dimanfaatkan oleh sebagian besar masyarakat pedalaman salah satunya pemanfaatan fauna atau satwa. Masyarakat sekitar hutan menjadikan hutan sebagai tumpuan hidup karena di dalam hutan terdapat satwa yang membentuk interaksi dan saling terkait (Wollenberg, et all. 2001). Desa Manggala merupakan salah satu Desa di Kabupaten Melawi yang memiliki masyarakat dengan kearifan lokal yang sangat kuat. Secara geografis Desa Manggala di kelilingi Hutan adat masyarakat dan Hutan produksi, jarak terdekat kehutan sekitar 30 menit dengan berjalan kaki. Kondisi alam yang mendukung masyarakat Desa Manggala Secara tradisional dan masih melakukan kegiatan berburu di hutan serta mencari ikan di sungai. Dayak Kubin merupakan salah satu masyarakat Desa 
Manggala yang melakukan kegiatan berburu dengan cara tradisional.

Masyarakat Dayak Kubin yang tinggal di Desa Manggala memanfaatkan satwa liar sebagai sumber protein untuk keperluan sehari-hari. Manfaat satwa liar sebagai sumber pangan yaitu sebagai sumber protein hewani yang memiliki nilai gizi yang baik, selain untuk dikosumsi biasanya juga digunakan sebagai obat atau untuk mengobati suatu penyakit. Pemanfaatan satwa liar sebagai bahan pangan (makanan) terutama pada daging. Pemanfaatan secara langsung misalnya dengan cara pengambilan telur, sedangkan pemanfaatan secara tidak langsung yaitu dengan pengambilan daging, dan ada juga untuk keperluan ritual adat, pengobatan, kegiatan supranatural dan komersial. Masyarakat dalam mendapatkan satwa liar masih mengunakan teknik-teknik dan alat tradisional sesuai dengan nilai-nilai kearifan lokal masyarakat, hal ini sesuai dengan konsep Etnoteknologi. Perburuan tradisional adalah perburuan yang dilakukan masyarakat Dayak Kubin dengan menggunakan alat-alat tradisional yang dipadukan dengan teknik berburu sesuai kearifan lokal, seperti mengunakan anjing pemburu, tali penjerat (perangkap), sumpit, tombak, panah, tuba akar untuk berburu ikan di sungai dan bubu untuk menangkap ikan di sungai masih dilakukan masyarakat. Berdasarkan hal tersebut perlu dilakukan penelitian tentang etnoteknologi Dayak Kubin di Desa Manggala Kecamatan Pinoh Selatan Kabupaten Melawi dalam upaya untuk mengetahui dan mendalami tata cara atau teknik berburu dan alat berburu tradisional Dayak Kubin.

\section{METODE PENELITIAN}

Penelitian ini dilaksanakan di Desa Manggala Kecamatan Pinoh Selatan Kabupaten Melawi. Waktu penelitian dilakukan mulai Januari - Februari 2019 efektif di lapangan dan dilanjutkan dengan pengolahan data. Alat yang digunakan dalam penelitian antara lain daftar pertanyaan atau kuisioner untuk responden terpilih, alat tulis untuk mencatat informasi dan data yang diperoleh di lapangan, alat rekaman untuk merekam hasil wawancara yang dilakukan di lapangan, kamera untuk mendokumentasi hasil penelitian di lapangan dan Tally Sheet, digunakan untuk mempermudah penelitian.Objek penelitian dalam penelitian ini yaitu teknik dan alat berburu masyarakat Dayak Kubin di Desa Manggala.

Penelitian ini dilaksanakan dengan metode survei dengan teknik wawancara, semi struktur dan penentuan responden dengan mengunakan Purposive Sampling atau menentukan sampel secara sengaja (Slovin dalam Umar 2005). Penentuan responden dengan mengunakan Purposive sampling dimana responden yang dipilih memiliki kreteria yaitu, masyarakat asli suku Dayak Kubin, mereka yang memiliki pengetahuan tentang alam, alat berburu serta cara pengolahan hasil buruan di Suku Dayak Kubin, berumur 25 tahun ke atas dan sudah menetap di Desa Manggala selama 5 tahun ke atas.

Jenis data yang dikumpulkan dalam penelitian ini terdiri atas data primer dan data sekunder. Data primer merupakan suatu data yang diperoleh dari hasil 
wawancara secara langsung di lapangan pada objek penelitian tersebut, yakni Masyarakat Dayak Kubin di Desa Manggala. Data Primer yang diambil pada penelitian ini yaitu : nama hewan, cara mendapatkan, teknik berburu, manfaat, bagian yang digunakan, cara pengolahannya, dan cara penggunaannya. Data sekunder merupakan suatu data yang bersifat penunjang yaitu data yang diperoleh dari literatur, serta data-data yang lainnya. Data tersebut meliputi keadaan umum lokasi, letak dan luas, pendidikan, keadaan sosial ekonomi masyarakat serta data sarana dan prasarana penghubung atau aksesibilitas ke Desa
Manggala. Analisa data yang digunakan adalah analisis deskriftif kualitatif, yaitu mendeskrifsikan data yang dikumpulkan. Data yang berasal dari wawancara, catatan lapangan, jenis hewan yang dimanfaatkan, cara mendapatkan dengan teknik berburu dan memanfaatkannya serta kegunaannya.

HASIL DAN PEMBAHASAN

\section{Karateristik Masyarakat Pemburu} Dayak Kubin

Karateristik masyarakat pemburu suku Dayak Kubin di Desa Manggala Kecamatan Pinoh Selatan Kabupaten Melawi terdapat 5 (lima) karakteristik.Karakteristik masyarakat Dayak Kubin dapat dilihat pada tabel 1.

Tabel 1. Karateristik Masyarakat Pemburu Dayak Kubin (Characteristick Public of Dayak Kubin Hanter)

\begin{tabular}{|c|c|c|c|}
\hline No & Karakteristi & Keterangan & Yang di Peroleh \\
\hline 1 & Pemanfaatan Hewan berdasarkan tempat & $\begin{array}{ll}\text { - } & \text { Hutan } \\
\text { - Sungai }\end{array}$ & $\begin{array}{l}\text { - Daging Hewan } \\
\text { - Daging Ikan }\end{array}$ \\
\hline 2 & Tempat Tinggal Masyarakat & $\begin{array}{l}\text { - Berkelompok } \\
\text { - Menyebar }\end{array}$ & $\begin{array}{l}\text { - } \quad \text { Tinggal berkelompok di } \\
\text { satu desa } \\
\text { - Menyebar di Kecamatan } \\
\text { Pinoh Selatan }\end{array}$ \\
\hline 3 & Mata Pencaharian & - Bertani & $\begin{array}{l}\text { - } \text { Bertani karet dan } \\
\text { Berladang } \\
\text { - } \text { Berburu Hewan dan } \\
\text { berburu ikan }\end{array}$ \\
\hline 4 & Tingkat Pemburu & $\begin{array}{l}\text { - Pemburu tertua } \\
\text { tidak aktif } \\
\text { - Pemburu tertua } \\
\text { Aktif } \\
\text { - Pemburu muda }\end{array}$ & $\begin{array}{ll}\text { - } & \text { Bapak Antunius Lonoh } \\
\text { dan Bapak Mahadar } \\
\text { - } & \text { Bapak Sina, Bapak Jan } \\
\text { Jono, Bapak Marden } \\
\text { dan Bapak Taman } \\
\text { - } \\
\text { Bapak Paulus, Bapak } \\
\text { Lorensius, Bapak } \\
\text { Sadam, Bapak Horia } \\
\text { dan Bapak Pebri }\end{array}$ \\
\hline 5 & Cara Berburu & $\begin{array}{l}\text { - Berkelompok } \\
\text { - Perorangan }\end{array}$ & $\begin{array}{l}\text { - Pergi berburu lebih dari } \\
2 \text { orang } \\
\text { - Pergi berburu 1-2 orang }\end{array}$ \\
\hline
\end{tabular}

Sumber: Analisis data primer 2019 
Masyarakat Dayak Kubin ini memiliki keragaman dalam pemanfaatan hewan baik untuk bahan pangan/ konsumsi. Masyarakat Dayak Kubin hidup secara berkelompok di Desa Manggala dan tinggal di rumah pribadi. Keseharian masyarakat Dayak Kubin ini adalah berburu dan bertani, kegiatan berburu merupakan kegiatan sampingan masyarakat Dayak Kubin yang bertujuan untuk memenuhi kebutuhan akan protein dan daging dalam keluarga. Mata pencarian hidup yang utama dari masyarakat Dayak Kubin adalah bertani. Berdasarkan hasil data penelitian pada masyarakat Dayak Kubin memiliki berbagai tingkat pemburu dari yang muda sampai tua, Bapak Amen Ungai sebagai Kepala Suku/Kepala adat Dayak Kubin. Masyarakat yang sering melakukan kegiatan berburu dari dulu yaitu Bapak Mahadar, Bapak Antonius Lonoh, Bapak Sina, Bapak Marden, Bapak Jan jono, Bapak Taman, Bapak Paulus, Bapak Sadam, Bapak Lorensius, Bapak Horia dan Bapak Pebri.

Lokasi berburu tidak jauh jika dengan berjalan kaki dari desa hanya menempuh 4-5 jam sampai ketempat camp, jika menggunakan sepeda motor hanya menempuh waktu 2-3 jam. Camp tempat

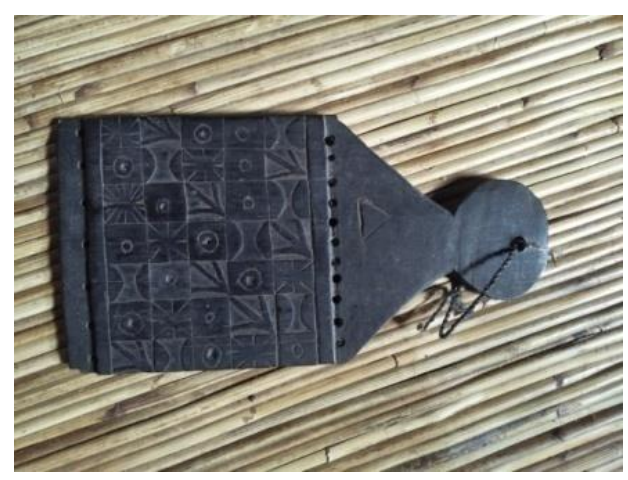

mereka menginap masih jauh dari tempat pemasangan langai (jerat) menempuh waktu 1 jam berjalan kaki. Masyarakat Dayak Kubin sama sekali tidak ada pantangan dalam memakan hewan, hanya hewan-hewan beracun yang tidak dapat dimakan yang tidak mereka makan. Sebelum melakukan kegiatan berburu mereka biasa mempersiapkan peralatan yang akan dibawa karena apabila ada peralatan yang tertinggal mereka tidak bisa kembali mengambil alat tersebut melainkan alat tersebut harus diantar oleh keluarga mereka ketempat mereka berburu. Anjing merupakan hewan yang wajib dibawa ketika berburu karena daya penciuman anjing bisa mendeteksi bau dari satwa buruan, ketika akan melakukan kegiatan berburu kondisi anjing juga harus sehat. Masyarakt Dayak Kubin sebelum berangkat harus menentukan waktu berburu berdasarkan penanggalan dengan alat beburu yaitu nyicuk ari yang terbuat dari kayu ulin (Eusideroxylon zwageri). Dayak Kubin juga bisa melihat hari-hari dimana mereka bisa mendapatkan hasil buruan namun cara untuk membaca hari berburu hanya dilakukan oleh tetua-tetua dari pemburu Dayak Kubin. Alat nyicuk ari dan anjing berburu dapat dilihat pada gambar 1 dan 2 .

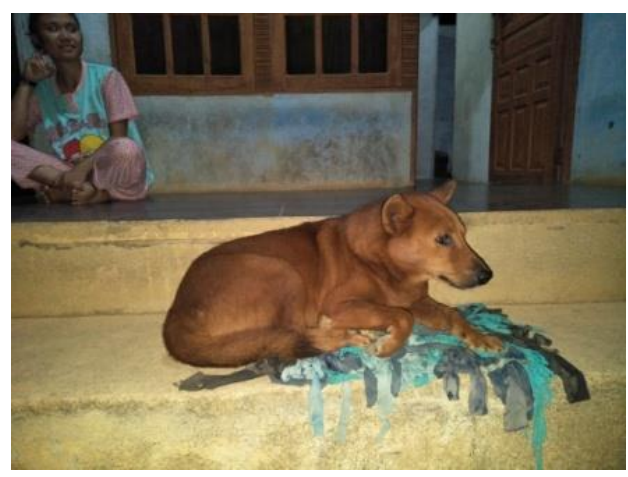


Gambar 1. Alat Menghitung Hari Berburu (Day Counter Tools for Hunting)

Saat ini masyarakat Dayak Kubin sudah tidak pernah menggunakan alat nyicuk hari karena populasi satwa sudah berkurang selain itu pemburu-pemburu yang usianya relatif muda sudah tidak mempercayai alat nyicuk hari, ketika mereka berburu mereka hanya mengandalkan rejeki ( ngadu heng).

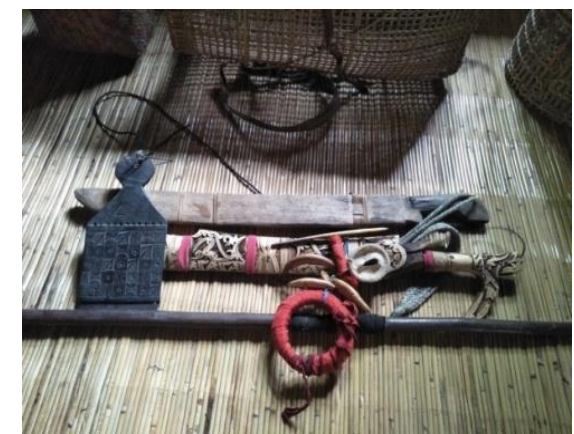

Gambar 3.Alat Berburu (Hunting Gear)

Kegiatan berburu biasa dilakukan kurang lebih \pm 1 minggu, oleh karena itu mereka harus membawa bekal mentah. Mereka tidak boleh membawa lauk hanya boleh membawa cabek, bawang merah bawang putih, minyak goreng, beras dan garam micin saja, kalau mereka membawa daging mereka akan sial dan tidak akan mendapatkan hasil buruan apapun, dan apa yang didapat berburu mereka akan jadikan lauk untuk makan. Kegiatan berburu tidak tergantung musim atau waktu tertentu karena jika masyarakat tidak ada kesibukan lain atau tidak ada kerjaan maka mereka akan melakukan kegiatan beburu. Berbeda hal nya dengan beberapa kelompok suku di Papua New Guinea, pelaksanaan musim
Gambar 2. Anjing Pemburu

(Hunter dog)

Peralatan yang akan dibawa masyarakat Dayak Kubin berburu adalah Tombak, Parang atau Mandau, Tas tengkalang Tas Rojut yang terbuat dari rotan, kulit kayu dan bambu untuk membawa hasil buruan, Tali nilon untuk membuat jerat buruan. Untuk peralatan berburu dapat dilihat pada gambar 3 dan 4 .

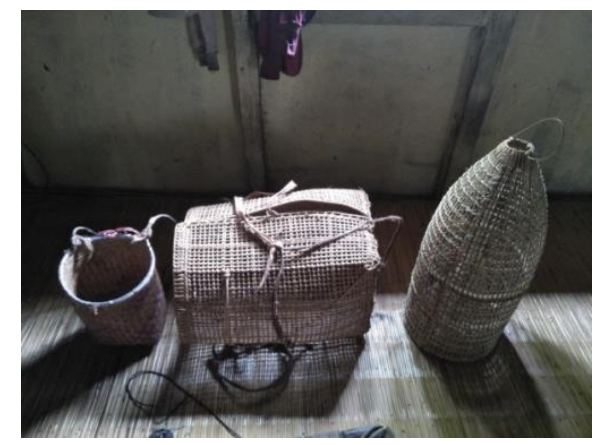

Gambar 4. Tas Tengkalang, Bubu dan Rojut (Tengkalangbag, Bubu and Rojut)

berburu juga berlaku dalam kaitannya dengan aktivitas pertanian masyarakat setempat misalnya setelah musim panen, musim menanam dan musim paceklik (Sillitoe, 2002). Praktek yang sama ditemukan hampir di sebagian besar wilayah Afrika (Ntiamoa-Baidu, 1997).

Tradisi masyarakat Dayak Kubin sebelum berburu melakukan ritual Emposek Jari (mengigit telunjuk jari) pada saat melewati tangga rumah agar selama mereka berburu akan selamat. Wilayah berburu masyarakat Dayak Kubin bebas dan untuk mengetahui batasan wilayah pemburu biasanya sudah mengenal lokasi dan tanda tanda jerat yang terpasang dengan cara melihat warna tali jerat, bekas jalan 
yang sudah mereka lewati ketika mereka memasang jeratan. Batasan wilayah pemburu tidak dibatasi karena mereka melakukan kegiatan berburu secara liar sehingga untuk memasuki wilayah tersebut pemburu tidak memerlukan ijin atau batasan untuk berburu tetapi jika masyarakat Dayak Kubin berburu kedaerah lain mereka harus meminta ijin ke kepala suku atau kepala adat yang ada di daerah hutan tersebut, jika mereka tidak meminta ijin mereka akan mendapatkan sangsi atau akan terkena adat butang.

\section{Teknik Berburu}

Berdasarkan hasil dari wawancara kepada masyarakat Dayak Kubin didapatkan 5 (lima). Hal ini sesuai dengan berdasarkan hasil penelitian dari (Freddy dan George, 2010), orang Maybrat di Papua mengenal 5 (lima) cara berburu, meniru suara binatang dan jerat. Kegiatan berburu mata, busur dan panah terbuat dari gelegah (bambu) yang dalam bahasa Maybrat disebut sawiya ara. Teknik berburu yang dilakukan masyarakat Dayak Kubin yaitu:

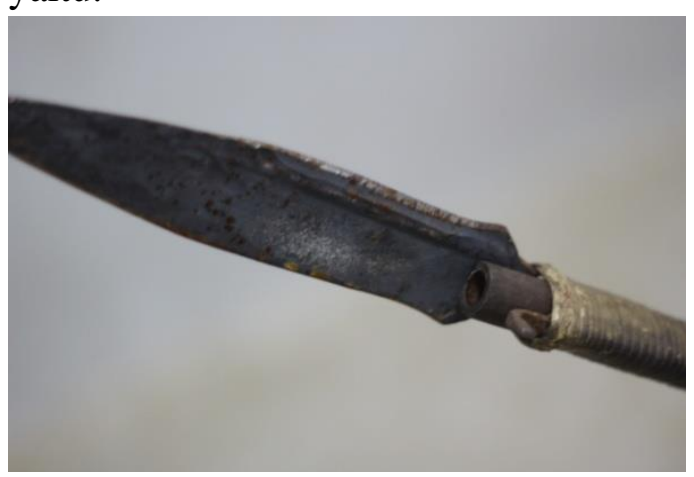

Gambar 5. Mata Tombak dan Lubang Sumpit (Spearhead and Chopstick Hole)

\section{b. Jerat (Langai)}

\section{a. Tombak (Lunju)}

Sejarah nenek monyang suku Dayak Kubin ada namanya senjata Rohak dimana senjata ini dapat digunakan dengan dua cara yaitu dijadikan tombak (lunju) dan sumpit dimana tombak beri lubang untuk dijadikan lobang sumpit, bagaimana bisa dijadikan sumpit karena bahannya terbuat dari kayu ulin (Eusideroxylon zwageri) dan ditengah kayu tersebut sudah dibuat lobang untuk menjadikan sumpit. Pemburu pada jaman nenek moyang suku Dayak Kubin mereka berburu babi dengan cara menggali lobang sedalam dalamnya di sekitaran yang terdapat pakan satwa yang ingin di buru, kemudian lobang ditutupi dengan kayu dan dedaunan, tetapi hal ini hanya dilakukan oleh pemburu jaman dulu dimasa sekarang berburu seperti itu sudah di tinggalkan. Cara menggunakan tombak yaitu kita melemparkan tombak kearah sasaran buruan dengan sekuatkuatnya supaya tombak tersebut tertancap kuat di sasaran buruan. Alat tombak dan sumpit dapat dilihat pada gambar 5 dan 6 .

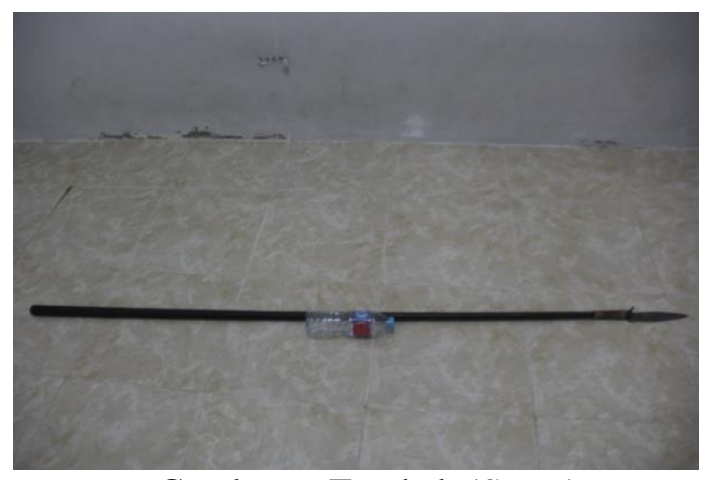

Gambar 6. Tombak (Spear)

Jerat terbuat dari batang kayu yang sangat kuat untuk mengikatnya harus 
mengguakan tali yang terbuat dari rotan yang sudah dibelah kecil. Penggunaan jerat supaya binatang buruan terperangkap pada jerat. Cara pembuatan jerat cukup dengan mengguanakan tali nilon yang berukuran sedang, diikat kepada pohon yang sudah kita potong ujungnya terlebih dahulu kemudian tali yang sudah diikat dengan pohon juga harus dibaluti dengan dedaunan supaya binatang tidak mengetahui jebakan tersebut. Jenis pohon juga harus yang

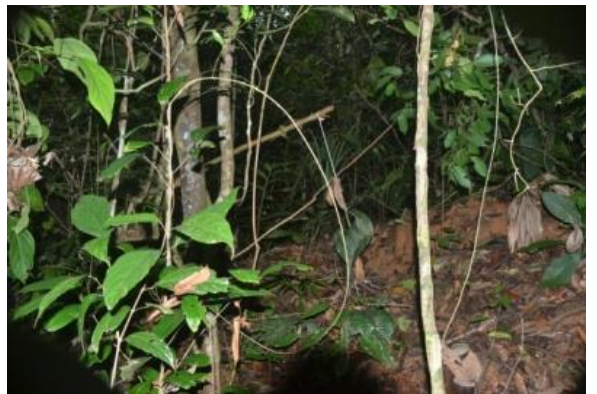

Gambar 7. Jerat (Trap)

\section{c. Bubu}

$B u b u$ terbuat dari tumbuhan pakupakuan dan bambu cara membuatnya tumbuhan paku yang sudah dikupas isinya diambil di rajut dengan bambu membentuk bulat supaya menjadi bubu. Pemburu memasang bubu pada sore dan ditunggu sampai malam ada pula dipasangkan sore dan di angkat besok kuat dan tidak mudah tercabut jika di tarik hewan buruan.Hal ini sesuai dengan hasil penelitian (Freddy et al., 2014) pemburu mengadopsi masyarakat di Papua penggunaan produk hutan seperti kayu, bambu dan rotan untuk membuat jerat, mendesain perangkap, membuat panah, busur dan tombak. Tumbuhan hutan yang elastis dan mudah untuk dibentuk, dilengkungkan serta tumbuhan penghasil serat tumbuhan diambil dan dianyam sebagai pengganti tali.

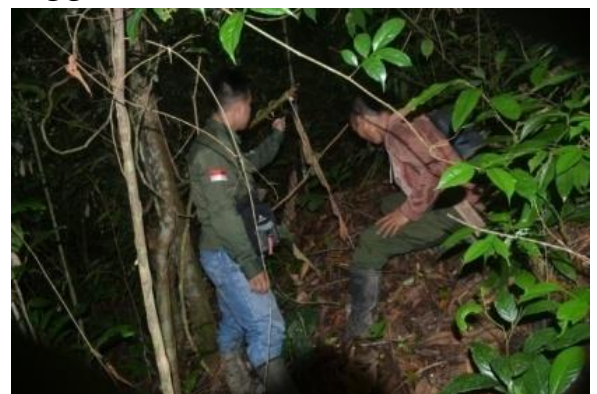

Gambar 8. Pemasangan Jerat (Trap Setting)

pagi. Bubu diletakan di tengah aliran anakan sungai diberi umpan serangga atau temboyak dari buah durian, untuk sungai besar bubu diletakan di pinggir sungai ditanjapkan kayu dan diikatkan bubu dengan kayu tidak lupa menimpakan bubu dengan dedaunan. Gambar bubu dapat dilihat pada gambar 9.

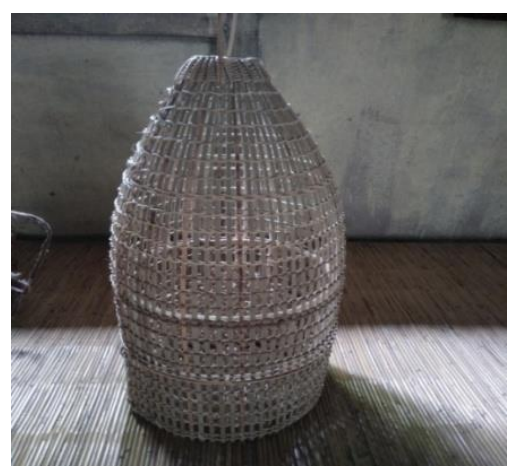

Gambar 9. Bubu (Fish Trap) 


\section{d. Najur (pancing)}

Pancing dibuat dengan menggunakan kayu kecil kemudian tali diikat dengan mata pancing diberi umpan serangga dan cacing ditunggu semalaman atau diangkat besok paginya pancing juga di pasangan di pinngir sungai kecil atau pinggiran sungai besar. Kegiatan berburu tidak hanya dilakukan di daratan melainkan dilakukan di sungai di Desa Manggala yaitu Sungai Bakah dan Sungai Mangat yang mengalir di Desa Manggala alat yang mereka gunakan untuk berburu ikan pancing.Jaman dulu teknik mencari ikan masyarakat Dayak Kubin mereka masi memasang perangkap ikan yang berbentuk bulat besar dan diberikan umpan, cara guna dari perangkap tersebut sangat unik karena jika ikan memakan umpan ikan tersebut akan terangkat kedaratan nama dari perangkap yaitu Bajut.

\section{e. Pukat}

Teknik berburu yang dilakukan masyarakat Dayak Kubin menggunakan jebakan pukat untuk menangkap burung di dalam hutan. Cara membuat perangkap burung dengan menggunakan tali pancing di rajut menyerupai pukat kemudian dipasangkan ditengah hutan ujung sisi dari pukat tersebut diikat diantara dua pohon kemudian diangkat pada besok hari. Jenis burung yang terperangkap sangat beragam seperti burung punai, burung tekukur, burung ruai.

Tabel 2. Rekapitulasi Teknik Berburu dan Jenis Satwa Buruan Dayak Kubin (Recapitulation of Hunting Techniques and Animal Were Hunted by Dayak Kubin)

\begin{tabular}{lll}
\hline No. & \multicolumn{1}{c}{ Alat Berburu } & Hewan Buruan \\
\hline 1. & Tombak (Lunju) & Babi \\
2. & Jerat (Langai) & Babi \\
& & Rusa \\
& & Kijang \\
& & Pelanduk \\
3. & Bubu & Ikan \\
4. & Najur (Pancing) & Ikan \\
5. & Pukat & Burung \\
\hline
\end{tabular}

3.

Jenis Satwa Yang Menjadi Sasaran Buruan

Berdasarkan hasil wawancara yang dilakukan di Desa Manggala,diperoleh responden sebanyak 12 orang. Wawancara yang dilakukan untuk memperoleh data mengenai jenis satwa yang menjadi sasaran buruan bagaimana teknik berburu Dayak Kubin di daerah tersebut. Jenis satwa yang menjadi sasaran buruan dapat dilihat pada Tabel 3. 
Tabel 3. Jenis Satwa yang Menjadi Sasaran Buruan (Species of Animals That Hunting Targeted)

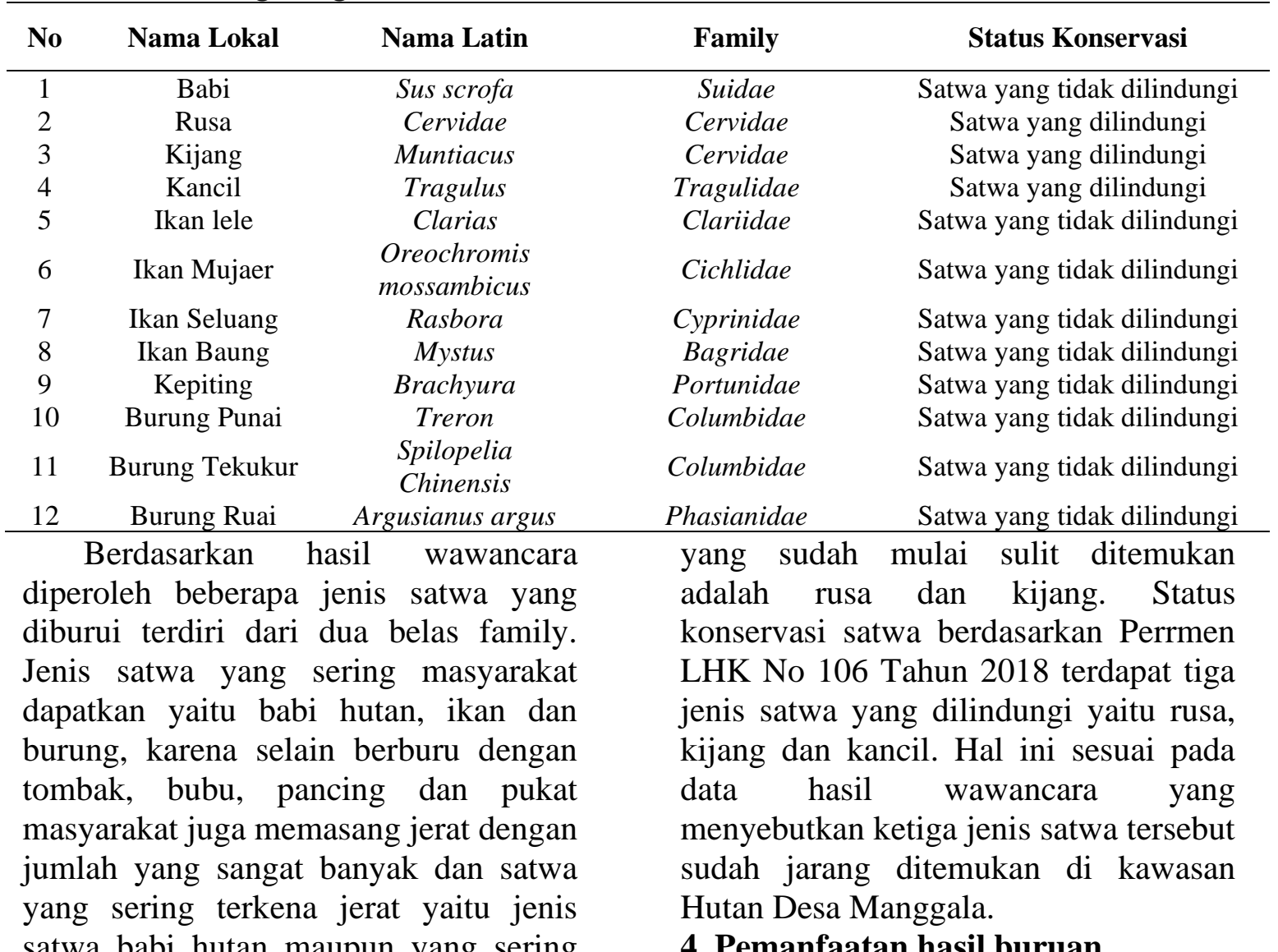
satwa babi hutan maupun yang sering terkena jerat pukat yaitu burung. Waktu berburu yang sering masyarakat lakukan yaitu pada pagi hari sampai dengan sore hari. Masyarakat juga berburu pada malam hari untuk menangkap ikan, melihat jebakan burung dan berburu kancil. Berdasarkan hasil wawancara dengan pemburu, jenis satwa/ hewan

Berdasarkan hasil wawancara yang dilakukan di Desa Manggala Kecamatan Pinoh Selatan Kabupaten Melawi bagian satwa yang di manfaatkan untuk dikosumsi dan dijadikan hiasan ajimat suku Dayak Kubin. Dapat dilihat di tabel 3.

Tabel 3. Pemanfaatan Hasil Buruan Yang di Kosumsi Dan Non Kosumsi (Utilization of Hunting Products to be Consumtion and Not Consumtion)

\begin{tabular}{ccccc}
\hline No & Jenis Hewan & Nama Latin & Kosumsi & Non Kosumsi \\
\hline 1 & Babi & Sus scrofa & Daging, Lemak dan Kulit & Kepala \\
2 & Kijang & Muntiacus & Daging dan kulit & Kepala \\
3 & Rusa & Cervidae & Daging dan kulit & Kepala \\
\hline \multicolumn{3}{c}{ Bagian hewan yang dikosumsi } & kosumsi langsung dipotong di lokasi \\
seperti bagian daging, lemak, kulit, & berburu jika mereka mendapatkan hasil \\
perut dan bagian yang bisa di makan & buruan yang sangat banyak mereka \\
lainya. Daging hasil buruan untuk & akan mengawetkan hasil buruan
\end{tabular}


tersebut dengan cara disalai (diasapkan) supaya hasil buruan tidak busuk dan masih awet dapat dilihat pada gambar 10, karena pemburu akan memasang langai (jerat) sampai puluhan dan ratusan dapat dilihat pada gambar 7 dan
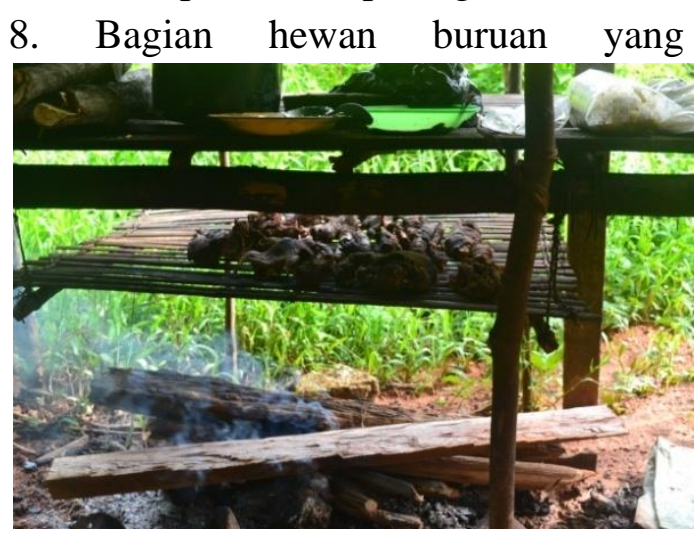

Gambar 10. Pengasapan Daging

(Fumigated Meat)

Daging hasil buruan babi, rusa, kijang dipotong terlebih dahulu di bersihkan dan bagian yang ingin diambil dipisahkan dari bagian yang tidak diambil seperti bagian perut yang tidak bisa diambil. Daging dipotong sedang kemudian daging bersih diasapkan diatas bara api yang sudah tersedia tempat pengasapan dan tidak lupa untuk meberikan daging yang tidak diasapkan dengan garam supaya daging tersebut tidak membusuk. Daging yang sudah diasapkan atau diberi garam dan daging yang masi baru didapat langsung dipotong ketika sudah sampai ke Desa Manggala daging lansung dibagikan digunakan di luar kosumsi (non konsumsi) seperti hiasan, ajimat dan sebagainya, dapat dilihat pada gambar no 11 . Jenis hewan yang bagian nya di gunakan untuk kebutuhan kesenian ataupun ajimat harus hewan yang berumur sangat tua.

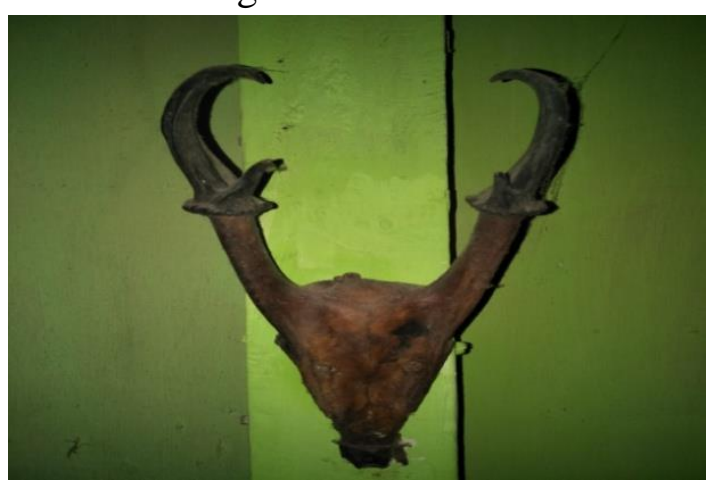

Gambar 11. Hiasan Kepala Rusa

(Decoration of a Deer's Head)

sesama pemburu untuk kebutuhan kosumsi, dapat dilihat pada gambar 12 dan 13. Hal ini tidak jauh beda dengan hasil penelitian yang dilakukan oleh Ngindra (1999) Suku Kenyah di Kecamatan Long Pujungan, yang menyebutkan hasil buruan sepenuhnya dimanfaatkan untuk kosumsi dan tidak ada kegiatan perjual hasil buruan, sekalipun berskala lokal. Untuk pengolahan hasil buruan masyarakat Dayak Kubin kepala kijang dan taring babi dipisahkan sendiri karena kepala kijang akan di jadikan kesenian sedangkan taring babi dijadikan sebagai jimat. 


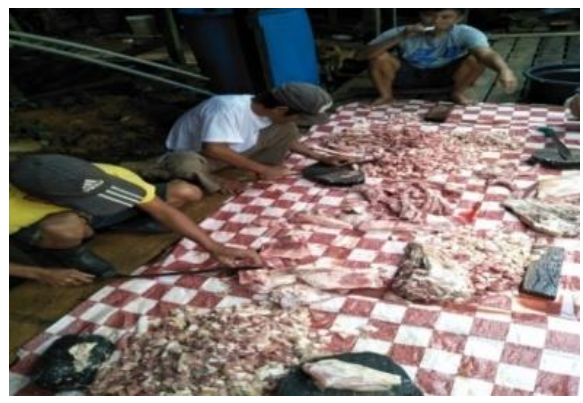

Gambar 12. Pembagian Daging (Meat distributions)

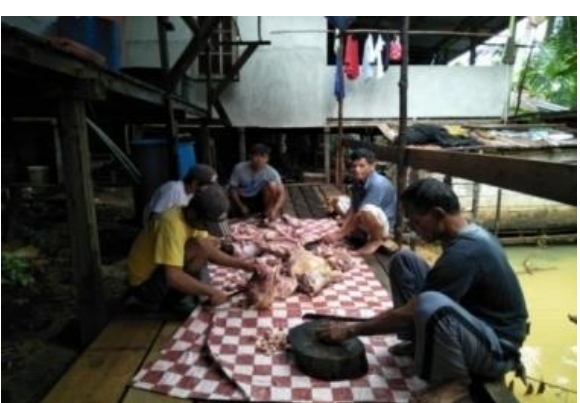

Gambar 13. Pengolahan Daging

(Meat Processing)

\section{Kesimpulan}

Berdasarkan hasil penelitian tentang etnoteknologi berburu Dayak Kubin di Desa Manggala Kecamatan Pinoh Selatan Kabupaten Melawi dapat disimpulkan bahwa: Kegiatan berburu masyarakat Dayak Kubin dilakukan dengan cara berkelompok dan perorangan. Alat yang digunakan dalam kegiatan berburu yaitu tombak, jerat, pukat, bubu dan pancing. Teknik berburu yang dilakukan masyarakat Dayak Kubin masih menggunakan cara tradisional seperti bahan-bahan yang digunakan masih berasal dari tumbuhan hutan seperti dedaunan dan kulit kayu yang dibuat ramuan, melakukan ritual sebelum beburu.Jumlah jenis hewan yang dimanfaatkan dan menjadi sasaran buruan oleh masyarakat Dayak Kubin di Desa Manggala Kecamatan Pinoh Selatan Kabupaten Melawi, yaitu sebanyak 12 jenis hewan dari 12 famili tersebut 2 jenis hewan 1 famili terdiri dari 1 spesies.

\section{Saran}

Kurangnya pengetahuan masyarakat di Desa Manggala Kecamatan Pinoh Selatan Kabupaten Melawi mengenai status perlindungan satwa sehingga diperlukan sosialisasi mengenai status konservasi satwa kepada masyarakat setempat.Perlu adanya penelitian lebih lanjut tentang jenis-jenis hewan buruan yang dapat di manfaatkan sebagai sumberdaya ekonomimasyarakat Dayak Kubin.

UCAPAN TERIMAKASIH

Ucapan terimakasih yang sebesarbesarnya kepada ketua adat, tumenggung dan pemburu Dayak Kubin Desa Manggala Kecamatan Pinoh Selatan Kabupaten Melawi yang telah menyediakan waktu dan banyak membantu peneliti selama proses penelitian hingga selesai.

\section{DAFTAR PUSTAKA}

Freddy P dan M George. 2010. Kearifan Tradisional Suku Maybrat Dalam Pemburuan Satwa Sebagai Penunjang Pelestarian Satwa. Vol. 14, No. 2: 75-82.

Freddy P, M Jacob, YSA Agustina dan M Herman. 2014. Pengelolaan dan Konservasi Satwa Berbasis Kearifan Tradisional di Papua. $J$. Manusia dan Lingkungan. Vol 22. No.1: 106-112.

Ngindra F. 1999. Pemenuhan Kebutuhan Pangan pada Mayarakat Suku Kenyah Bakung 
di Desa Long Aran. dalam :

Eghenter C, Sellato B. Kebudayaan dan Pelestarian Alam Penelitian Interdisipliner di Pedalaman Kalimantan.. Niemitz, C. 1979b. Outline of the Behavior of Tarsiusbancanus. Hlm. 631660.43. WWF Indonesia. Jakarta.

Ntiamoa-Baidu Y. 1997. Wildlife and Food Security in Africa. FAO Conservation Guide 33 www.fao.org/docrep/W7540E.

Sillitoe P, 2002. Always been Farmerforagers. Hunting and Gathering in the Papua New Guinea Highlands. Anthropological Forum, 12(1):45-76.

Umar H. 2005. Riset Sumber Daya Manusia dalam Organisasi. Gramedia Pustaka Utama. Jakarta.

Wollenberg EA, Uluk dan M Sudana. 2001. Ketergantungan Masyarakat Dayak Terhadap Hutan di Sekitar Taman Nasional Kayan Mentarang. CIFOR. Bogor. 